\title{
Evaluation of Choroidal Thickness, Retinal Nerve Fiber Layer Thickness, Macular Thickness and Retinal Vessel Diameter by Optical Coherence Tomography in Patients with Peripheral Arterial Disease
}

\section{Periferik Arter Hastalığı Olan Olgularda Optik Koherens Tomografi ile Koroid Kalınlığı, Retina Sinir Lifi Tabakası Kalınlığı Maküla Kalınlığı ve Retina Damar Çapı Ölçümlerinin Değerlendirilmesi}

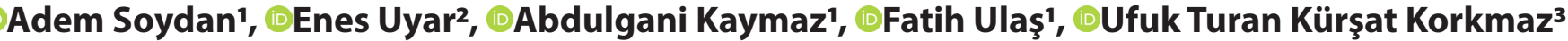 \\ 'Bolu Abant Izzet Baysal University, Faculty of Medicine, Department of Ophthalmology, Bolu, Turkey \\ ${ }^{2}$ Aksaray University, Training and Research Hospital, Department of Ophthalmology, Aksaray, Turkey \\ ${ }^{3}$ Bolu Abant Izzet Baysal University, Faculty of Medicine, Department of Cardiovascular Surgery, Bolu, Turkey
}

\begin{abstract}
Aim: To evaluate retinal nerve fiber layer thickness, macular thickness and retinal vessel diameter by optical coherence tomography in patients with peripheral artery disease.

Material and Method: 35 patients with a diagnosis of peripheral arterial disease (PAD) and 32 healthy individuals (control group) were included in the study. Retinal thickness (RT), choroidal thickness (CT) in enhanced depth imaging (EDI) mode, retinal nerve fiber layer (RNFL) thickness, retinal artery and vein diameters were measured with optical coherence tomography (OCT) device.

Results: The mean age of the PAH group included in the study was $59.4 \pm 11.9$ and the mean age of the control group was $55.5 \pm 5.3$ years. A statistically significant difference was observed between the two groups in the values obtained from the CT in the subfoveal region of the EDI measured from three different regions and the nasal quadrant of the RNFL measured from 7 quadrants $(p=0.03$ and $p=0.03$, respectively). On the contrary, no statistically significant difference was observed in EDI and other measurements of RNFL, RT values, artery and vein diameters ( $p$ values were between 0.08 1.00).

Conclusion: In patients with PAD, it is important to determine the RNFL and CT to be thinner. It can be a guide in more comprehensive studies in the future.
\end{abstract}

Keywords: Choroidal thickness, optical coherence tomography, peripheral artery disease, retinal nerve fiber layer thickness, retinal thickness.
Öz

Amaç: Periferik arter hastalığı olan olgularda optik koherens tomografi ile koroid kalınlığı, retina sinir lifi tabakası kalınlığı, maküla kalınlığı ve retina damar çapı ölçümlerini değerlendirmek.

Gereç ve Yöntem: Çalışmaya 35 periferik arter hastalığı $(P A H)$ tanıı hasta ve 32 sağlıkı birey (kontrol grubu) dahil edildi. Tüm bireylerin optik koherens tomografi (OKT) cihazıyla retina kalınlığı (RK), artırılmış derinlik görüntüleme (EDI) modunda koroid kalınlığı (KK), retina sinir lifi tabakası (RSLT) kalınlığı, retina arter ve ven çapı ölçümleri yapıldı.

Bulgular: Çalışmaya dahil edilen PAH grubunun yaş ortalaması $59.4 \pm 11.9$ ve kontrol grubunun yaş ortalaması $55.5 \pm 5.3$ yıl idi. Üç farklı bölgeden ölçülen EDI'nin subfoveal bölgedeki KK'da ve 7 kadrandan ölçülen RSLT'nin nazal kadranından elde edilen değerler iki grup arasında istatistiksel olarak anlamlı farklılık gözlendi (sırasıyla, $p=0,03$ ve $p=0,03)$. Aksine EDI ile RSLT'nin diğer ölçümleri, RK değerleri, arter ve ven çapları ölçümlerinde istatistiksel olarak anlamlı bir farklılık gözlenmedi ( $p$ değerleri 0,08-1,00 arasında idi).

Sonuç: PAH hastalarında RSLT ve koroid tabakası kalınlığının daha ince olarak saptanması önemlidir. Ileride yapılacak daha kapsamlı çalışmalarda yol gösterici olabilir.

Anahtar Kelimeler: Koroid kalınlığı, optik koherens tomografi, periferik arter hastalığı, retina kalınlığı, retina sinir lifi tabakası kalınlığı 


\section{INTRODUCTION}

Peripheral arterial disease (PAD) is a systemic progressive atherosclerotic disease usually manifested by obstruction or occlusion of the lower extremity arteries. Subclinical inflammation, oxidative stress and endothelial dysfunction play a role in the atherosclerotic process. The development of atherosclerosis is a multifactorial and very complex process that affects various genetic and environmental factors. ${ }^{[1]}$ Atherosclerotic PAD, which affects all body arteries can also cause blockages in the retinal arteries and arterioles.

The veins of the retina are the only areas in the body where the circulation can be viewed directly by non-invasive methods. Digital imaging techniques developed in recent years have enabled better visualization of microvascular changes of the retina such as arteriolar narrowing of the retina and venular dilatation. Examination of retinal vessels is a valuable non-invasive option for the investigation of microvascular diseases. ${ }^{[2]}$ The diameter of the retinal vessels is affected by oxygenation of the retina, and it has been suggested that dilatation of retinal venules may indicate retinal hypoxia. ${ }^{[3]}$ It has been reported that arteriole and venule diameters should be evaluated separately since the ratio of arteriole/venule diameter provides limited information. ${ }^{[4]}$

The optical coherence tomography (OCT) device is commonly used in retinal imaging today. By performing segmentation analysis with different acquisition modes of the OCT device, it is possible to measure the thickness of the retina layers separately, as well as the thickness of the choroidal layer manually.

We think that the choroid, retina and retinal nerve fiber layer (RNFL) are affected in PAD due to the dense vascular and neuronal structure of the eye and its sensitivity to systemic changes. Therefore, in this study, we planned to investigate the effect of PAD on retinal thickness, choroidal thickness, and retinal vessel diameters.

\section{MATERIALS AND METHODS}

The present study was carried out in accordance with the principles of the Declaration of Helsinki, after the approval of the Scientific Research Ethics Committee of Bolu Abant Izzet Baysal University (No: 2020/252, Date:27.10.2020). Participants were informed about the study and their written consent was obtained.

The study was carried out prospectively between January 2020 and April 2020 at Bolu Abant İzzet Baysal University Eye Disease Clinic. Patients diagnosed with PAD in the cardiovascular surgery clinic were referred to the ophthalmology clinic. Thirty five patients with PAD (study group) and 32 healthy volunteers without PAD (control group) were included in the study. The ages of the individuals ranged between 42-80 years. Basic clinical and demographic characteristics of all participants were recorded, and afterward, a detailed eye examination was performed, and measurements were taken by OCT. All data obtained were evaluated by comparing between groups.

\section{OCT Measurements}

Retinal thickness (RT), choroidal thickness (CT) in enhanced depth imaging (EDI) mode and RNFL thickness were measured with the Spectralis ${ }^{\circledR}$ OCT device (Heidelberg Engineering, Heidelberg, Germany) (Figure 1). The OCT device automatically measures RT and RNFL (Figure 1A). However, CT measurements were manually measured in EDI mode from the foveal center, $1500 \mu \mathrm{m}$ temporal, and $1500 \mu \mathrm{m}$ nasal of the fovea (Figure 1B). Retinal artery and vein diameters were manually calculated in RNFL mode from the artery and vein that originated from the optic disc and extended towards the superior temporal, $1800 \mu \mathrm{m}$ away from the center of the optic disc. In order to make precise measurements, the areas where the vessels do not bifurcate with $2 \mathrm{X}$ magnification were selected (Figure 1C).

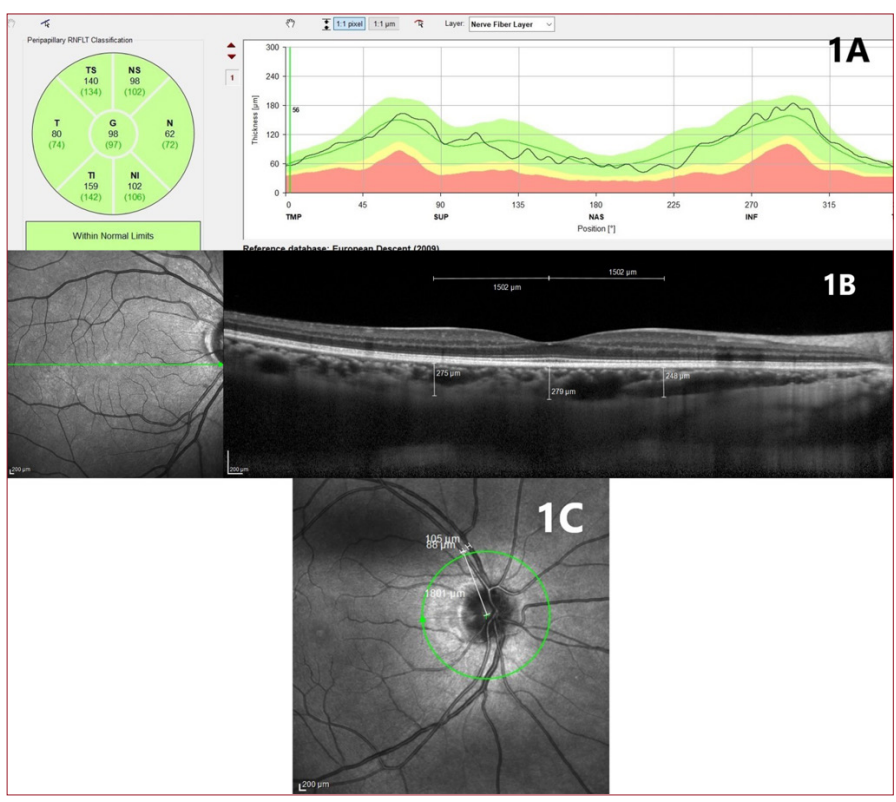

Figure 1. OCT measurements of the cases. 1A: Printout of RNFL measurements. 1B: Choroidal measurement in EDI mode. 1C: Retinal vessel diameter measurement (measured at $2 \mathrm{X}$ magnification).

\section{Statistical Analysis}

The statistical analysis of the results was made with the "SPSS for Windows 25.0" program. Results were evaluated as mean \pm standard deviation. If the obtained data met the criteria of normal distribution (by Shapiro-Wilk test) and homogeneity (by KMO and Barlett sphericity test), it was evaluated with an independent sample t-test. $P$ value less than 0.05 was considered statistically significant.

\section{RESULTS}

A total of 67 cases were included in the study. The demographic characteristics and ophthalmological measurements of the cases are given in Table 1. There was no statistically significant difference in age, gender, spherical equivalent, visual acuity, central corneal thickness (CCT), and intraocular pressure (IOP) between the groups ( $p$ value was between 0.08-0.78). 


\begin{tabular}{|c|c|c|c|}
\hline & $\begin{array}{c}\text { PAD group } \\
(n=35)\end{array}$ & $\begin{array}{c}\text { Control group } \\
(n=32)\end{array}$ & $\stackrel{P}{\text { value* }}$ \\
\hline Gender (Male/Female, n) & $30 / 5$ & $26 / 6$ & 0.65 \\
\hline Age (years) & $59.4 \pm 11.9$ & $55.5 \pm 5.3$ & 0.08 \\
\hline Smoking rates (\%) & $26 / 35(74 \%)$ & $9 / 32(28 \%)$ & $<0.01$ \\
\hline Visual acuity (decimal) & $0.90 \pm 0.13$ & $0.94 \pm 0.09$ & 0.17 \\
\hline Spherical equivalent (Diopter) & $0.24 \pm 1.08$ & $0.40 \pm 0.99$ & 0.56 \\
\hline IOP $(\mathrm{mmHg})$ & $14.97 \pm 4.08$ & $14.72 \pm 3.01$ & 0.78 \\
\hline $\mathrm{CCT}(\mu \mathrm{m})$ & $547.65 \pm 31.887$ & $542.71 \pm 25.589$ & 0.53 \\
\hline $\mathrm{RTc}(\mu \mathrm{m})$ & $221.78 \pm 25.284$ & $221.14 \pm 16.842$ & 0.90 \\
\hline $\mathrm{RTn}(\mu \mathrm{m})$ & $349.72 \pm 17.982$ & $352.69 \pm 18.013$ & 0.50 \\
\hline $\mathrm{RTt}(\mu \mathrm{m})$ & $326.28 \pm 17.456$ & $326.29 \pm 18.764$ & 1.00 \\
\hline CTs $(\mu \mathrm{m})$ & $274.16 \pm 69.189$ & $315.00 \pm 80.123$ & 0.03 \\
\hline$C \operatorname{Crn}(\mu \mathrm{m})$ & $231.00 \pm 71.589$ & $248.03 \pm 72.210$ & 0.34 \\
\hline $\mathrm{CTt}(\mu \mathrm{m})$ & $253.47 \pm 68.334$ & $276.26 \pm 68.032$ & 0.18 \\
\hline RNFL Global $(\mu \mathrm{m})$ & $99.38 \pm 13.495$ & $101.40 \pm 7.468$ & 0.47 \\
\hline RNFL Temporal superior $(\mu \mathrm{m})$ & $135.03 \pm 21.390$ & $138.37 \pm 16.044$ & 0.49 \\
\hline RNFL Temporal $(\mu \mathrm{m})$ & $71.00 \pm 10.429$ & $70.00 \pm 8.039$ & 0.67 \\
\hline RNFL Temporal inferior $(\mu \mathrm{m})$ & $149.47 \pm 21.834$ & $149.53 \pm 15.598$ & 0.99 \\
\hline RNFL Nasal superior $(\mu \mathrm{m})$ & $107.91 \pm 23.726$ & $108.87 \pm 18.131$ & 0.86 \\
\hline RNFL Nasal $(\mu \mathrm{m})$ & $71.56 \pm 16.078$ & $79.40 \pm 11.846$ & 0.03 \\
\hline RNFL Nasal inferior $(\mu \mathrm{m})$ & $117.28 \pm 27.270$ & $117.17 \pm 18.596$ & 0.98 \\
\hline Arterial diameter $(\mu \mathrm{m})$ & $88.33 \pm 9.215$ & $87.90 \pm 11.597$ & 0.88 \\
\hline Vein diameter $(\mu \mathrm{m})$ & $120.00 \pm 21.582$ & $117.90 \pm 17.685$ & 0.68 \\
\hline
\end{tabular}

When the RT measured from the central, nasal, and temporal areas and the CT measured from the temporal and nasal areas were compared, no statistically significant difference was found between the groups ( $p$ value was between 0.18-1.00). On the contrary, CT measured from the subfoveal was found to be statistically significantly lower in the PAD group $(p=0.03)$. Likewise, RNFL thickness was found to be significantly lower only in the nasal quadrant in the PAD group $(p=0.03)$. Apart from this, no statistically significant difference was found between the groups in arterial and vein diameters $(p=0.88$, $\mathrm{p}=0.68$, respectively).

\section{DISCUSSION}

The most important findings we obtained in our study; subfoveal $\mathrm{CT}$, and RNFL values in the nasal quadrant were found to be significantly lower in patients with PAD compared to the control group. The fact that the thickness of the choroidal layer measured from the subfoveal was significantly lower in the PAD group suggests that choroidal blood supply decreased in this group. However, no significant difference was found between the values of CT measured in the nasal and temporal quadrants. On the other hand, the fact that the RNFL value measured from the nasal quadrant was significantly lower in the PAD group compared to the control group may indicate that optic nerve blood supply was also impaired in these patients and retinal nerve fibers were damaged.
PAD is an important atherosclerotic disease that often involves the lower extremity arteries and is associated with high cardiovascular mortality and morbidity. ${ }^{[5]}$ The prevalence of PAD increases with age and reaches up to $20 \%$ in patients older than 70 years. ${ }^{[6]}$ The most important risk factors include smoking, advanced age, hypertension, diabetes mellitus, hyperhomocysteinemia and hyperlipidemia. ${ }^{[7,8]}$ Despite recent advances and new treatment options, PAD still causes limb ischemia, amputation or death. ${ }^{[9]}$ Atherosclerotic risk factors play an important role in the progression and development of PAD. Presence of PAD that seriously affects the retinal arterial bed is a clinical condition that can lead to blindness.

RNFL is formed by astrocytes, retinal vessels, and extensions of Müller cells, with approximately 1-1.2 million axons of retinal ganglion cells. Retinal nerve fiber bundles pass through openings called pores in the scleral canal. This part is the area where the retinal nerve fiber bundle is most susceptible to glaucomatous damage, and in severe damage, these holes appear as slits, causing the optic dimple to appear wide. ${ }^{[10]}$ The early sign of glaucomatous damage on OCT is a decrease in RNFL thickness. It has been suggested that various systemic factors such as advanced age, male gender, dyslipidemia, and hyperglycemia have an effect on RNFL thickness. ${ }^{[11]}$ Higher arterial blood pressure and higher concentration of low-density lipoproteins have been associated with localized RNFL defects. ${ }^{[11]}$ Considering that most patients with PAD have problems such as advanced age, male gender, hypertension and dyslipidemia, low RNFL thickness may be associated with this. In our study, the low RNFL thickness in the nasal segment that we observed in patients with PAD may be significant in more segments when adapted to large patient groups.

In addition to ocular problems, it is known that RNFL thickness may decrease due to many non-ocular reasons. When we look at studies examining RNFL thickness changes in some systemic diseases, it has been shown that RNFL thickness is lower in iron deficiency anemia, migraine without aura, obstructive sleep apnea syndrome and Alzheimer's disease. [12,13]

The choroid is a thin dense network of vessels that supply nutrients and oxygen to the outer retina, foveal avascular region, retinal pigment epithelium, and optic nerve between the retina and sclera. CT does not only change with pathological and pharmacological factors, age, the axial length of the eye, refractive changes, diurnal rhythm and perfusion pressure also affect $\mathrm{CT}$ changes. The root cause of these changes is still unknown. In a study by Ulaş et al. ${ }^{[14]}$, it was reported that there was a significant increase in choroidal thickness 5 minutes after smoking in adolescents and returning to the basal level at 60 minutes. There are also studies showing that $\mathrm{CT}$ is significantly lower in patients between the ages of 60 and 80 who smoke chronically compared to non-smokers. ${ }^{[15-17]}$ It is hypothesized 
that chronic smoking causes chronic vasoconstriction and direct oxidative damage to the endothelium, resulting in vascular thinning in some individuals and a thinner choroid as a result. There are many studies in which subfoveal CT is lower in patients with heart-related perfusion impairment, such as chronic heart failure and carotid artery disease. ${ }^{[17-20]}$ Choroidal hypoperfusion, choroidal ischemia and infarction may lead to multiple occlusions, leading to a reduction in $\mathrm{CT}$, since chronic smoking and cardiac diseases are often seen together in patients with PAD.

It is known that some ocular and systemic diseases, drugs used, and genetic factors cause changes in retinal arteriole and venule diameters. ${ }^{[21-23]}$ It has been found that the response of retinal venules to hemodynamic changes is reduced, vascular functions are impaired in smokers, and it has been suggested that the negative effects of smoking may occur without changes in the vessel diameter. ${ }^{[24]}$ Ulaş et al. ${ }^{[25]}$ also reported that there was no significant difference in retinal arteriole and venule diameters between smoking and non-smoking groups. Similarly, in our study, no significant difference was found in the arteriole and venule diameters in the PAD group compared to the control group.

The main limitations of our study are the relatively small number of patients and the fact that other systemic characteristics of the patients were not recorded and could not be associated with OCT results. In addition, the inability to include different ages and groups reduces the impact of the study. However, the positive findings obtained despite all limitations increase the importance of the study.

\section{CONCLUSION}

As a result, in our study, RNFL and thinning of the choroidal layer thickness were detected in PAD patients. Additional studies examining more parameters in larger populations are needed to better understand the mechanism and clinical significance of this thinning.

\section{ETHICAL DECLARATIONS}

Ethics Commite Approval: The study has ethical approval from Bolu Abant İzzet Baysal University Ethics Committee(No: 2020/252, Date:27.10.2020).

Informed Consent: All patients signed the free and informed consent form.

Referee Evaluation Process: Externally peer-reviewed.

Conflict of Interest Statement: The authors have no conflicts of interest to declare.

Financial Disclosure: The authors declared that this study has received no financial support.

Author Contributions: All of the authors declare that they have all participated in the design, execution, and analysis of the paper, and that they have approved the final version.

\section{REFERENCES}

1. Es MU, Senol S, Yuksel A, Kargun K. Endothelin-1 gene polymorphisms in patients with peripheral artery disease. Acta Med Mediterr 2016;32:897901.

2. Wong TY, Klein R, Klein BE, Tielsch JM, Hubbard L, Nieto FJ. Retinal microvascular abnormalities and their relationship with hypertension, cardiovascular disease, and mortality. Survey of ophthalmology 2001;46(1):59-80.

3. Stefansson E, Landers MB, Wolbarsht ML. Oxygenation and vasodilatation in relation to diabetic and other proliferative retinopathies. Ophthalmic Surgery, Lasers and Imaging Retina 1983;14(3):209-26.

4. Liew G, Sharrett AR, Kronmal R, et al. Measurement of retinal vascular caliber: issues and alternatives to using the arteriole to venule ratio. Investigative ophthalmology \& visual science 2007;48(1):52-7.

5. Fowkes FGR, Rudan D, Rudan I, et al. Comparison of global estimates of prevalence and risk factors for peripheral artery disease in 2000 and 2010: a systematic review and analysis. The Lancet 2013;382(9901):1329-40.

6. Norgren L, Hiatt WR, Dormandy JA, et al. Inter-society consensus for the management of peripheral arterial disease. Int Angiol 2007;26(2):81-157.

7. Chisari L, Malaguarnera S, Grasso A, et al. Cilostazol reduces dry eye symptoms and improve walking distance in patients with peripheral artery disease. La Clinica Terapeutica 2019;170(5):e357-e363.

8. Es MU, Senol S, Yuksel A. Is Hemoglobin A1c a valuable parameter in non-diabetic patients with peripheral arterial disease? Acta Med Mediter 2016;32:911-5.

9. Novo S, Coppola G, Milio G. Critical limb ischemia: definition and natural history. Current Drug Targets-Cardiovascular \& Hematological Disorders 2004;4(3):219-25.

10. Choplin NT. Retinal nerve fiber layer analysis. Oftalmoloji Barcelona, Spain: Mosby International Ltd 2004;248-9.

11. Zhang Y, Xu L, Zhang L, Yang H, Wang YX, Jonas JB. Ophthalmoscopic assessment of the retinal nerve fiber layer. The Beijing Eye Study. PloS one 2013;8(4):e62022.

12. Oncel Acir N, Dadaci Z, Cetiner F, Yildiz M, Alptekin H, Borazan M Evaluation of the peripapillary retinal nerve fiber layer and ganglion cell-inner plexiform layer measurements in patients with iron deficiency anemia with optical coherence tomography. Cutaneous and ocular toxicology 2016;35(2):131-6.

13. Güneş A, Demirci S, Tök L, Tök Ö, Demirci S. Evaluation of retinal nerve fiber layer thickness in Alzheimer disease usingspectral-domain optical coherence tomography. Turkish journal of medical sciences 2015;45(5):1094-7.

14. Ulaş F, Çelik F, Doğan Ü, Çelebi S. Effect of smoking on choroidal thickness in healthy smokers. Current Eye Research 2014;39(5):504-11.

15. Dervişoğulları MS, Totan Y, Tenlik A, Yüce A, Güler E. Effect of smoking on retina nerve fiber layer and ganglion cell-inner plexiform layer complex. Cutaneous and ocular toxicology 2015;34(4):282-5.

16. Kantarci FA, Tatar MG, Colak HN, et al. A pilot study of choroidal thickness in long-term smokers. Retina 2016;36(5):986-91.

17. Lareyre F, Nguyen E, Raffort J, et al. Changes in ocular subfoveal choroidal thickness after carotid endarterectomy using enhanced depth imaging optical coherence tomography: a pilot study. Angiology 2018;69:574-81.

18. Bulut M, Ayoğlu RU, Erol MK, Toslak D, Toslak IE. Evaluation of The Chorioretinal Thickness in Patients with Internal Carotid Artery Stenosis Using Spectral-Domain Optical Coherence Tomography. Retina-Vitreus/ Journal of Retina-Vitreous 2018;27(1).

19. Rabina G, Barequet D, Mimouni M, et al. Carotid artery endarterectomy effect on choroidal thickness: one-year follow-up. Journal of ophthalmology 2018;2018.

20. Sayin N, Kara N, Uzun F, Akturk IF. A quantitative evaluation of the posterior segment of the eye using spectral-domain optical coherence tomography in carotid artery stenosis: a pilot study. Ophthalmic Surgery, Lasers and Imaging Retina 2015;46(2):180-5.

21. Vinten M, Larsen M, Lund-Andersen H, Sander B, La Cour M. Short-term effects of intravitreal triamcinolone on retinal vascular leakage and trunk vessel diameters in diabetic macular oedema. Acta ophthalmologica Scandinavica 2007;85(1):21-6. 
22. Mitchell $\mathrm{P}$, Leung $\mathrm{H}$, Wang JJ, et al. Retinal vessel diameter and openangle glaucoma: the Blue Mountains Eye Study. Ophthalmology 2005;112(2):245-50.

23. Wong TY, Knudtson MD, Klein BE, Klein R, Hubbard LD. Medication use and retinal vessel diameters. American journal of ophthalmology 2005;139(2):373-5.

24. Garhöfer G, Resch H, Sacu S, et al. Effect of regular smoking on flicker induced retinal vasodilatation in healthy subjects. Microvascular research 2011;82(3):351-5.

25. Ulaş F, Çelik F, Doğan Ü, Çelebi S. Sigaranın Sağlıklı Genç Yetişkinlerin Retina Damar Çapı Üzerindeki Akut Etkilerinin Araştırılması. RetinaVitreus/Journal of Retina-Vitreous 2014;22(1). 